Argonne

\title{
An Evaluation of the Potential for Shifting of Freight from Truck to Rail and Its Impacts on Energy Use and GHG Emissions
}

Energy Systems Division 


\begin{abstract}
About Argonne National Laboratory
Argonne is a U.S. Department of Energy laboratory managed by UChicago Argonne, LLC under contract DE-AC02-06CH11357. The Laboratory's main facility is outside Chicago, at 9700 South Cass Avenue, Argonne, Illinois 60439. For information about Argonne and its pioneering science and technology programs, see www.anl.gov.
\end{abstract}

\title{
DOCUMENT AVAILABILITY
}

Online Access: U.S. Department of Energy (DOE) reports produced after 1991 and a growing number of pre-1991 documents are available free via DOE's SciTech Connect (http://www.osti.gov/scitech/).

Reports not in digital format may be purchased by the public from the National Technical Information Service (NTIS):

U.S. Department of Commerce

National Technical Information Service

5301 Shawnee Road

Alexandria, VA 22312

www.ntis.gov

Phone: (800) 553-NTIS (6847) or (703) 605-6000

Fax: (703) 605-6900

Email: orders@ntis.gov

Reports not in digital format are available to DOE and DOE contractors from:

U.S. Department of Energy

Office of Scientific and Technical Information

P.O. Box 62

Oak Ridge, TN 37831-0062

\footnotetext{
Disclaimer

This report was prepared as an account of work sponsored by an agency of the United States Government. Neither the United States Government nor any agency thereof, nor UChicago Argonne, LLC, nor any of their employees or officers, makes any warranty, express or implied, or assumes any legal liability or responsibility for the accuracy, completeness, or usefulness of any information, apparatus, product, or process disclosed, or represents that its use would not infringe privately owned rights. Reference herein to any specific commercial product, process, or service by trade name, trademark, manufacturer, or otherwise, does not necessarily constitute or imply its endorsement, recommendation, or favoring by the United States Government or any agency thereof. The views and opinions of document authors expressed herein do not necessarily state or reflect those of the United States Government or any agency thereof, Argonne National Laboratory, or UChicago Argonne, LLC.
} 


\section{An Evaluation of the Potential for Shifting of Freight from Truck to Rail and Its Impacts on Energy Use and GHG Emissions}

by

Yan Zhou, Anant Vyas, and Zhaomiao Guo

Energy Systems Division, Argonne National Laboratory

June 2017 



\section{CONTENTS}

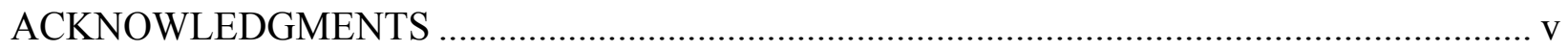

GENERAL ACRONYMS, INITIALISMS, AND ABBREVIATIONS ................................... vi

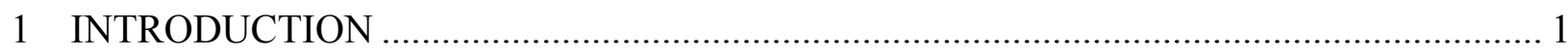

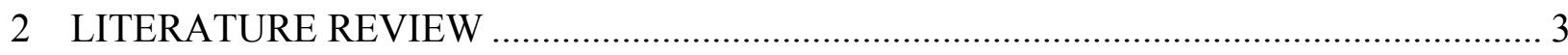

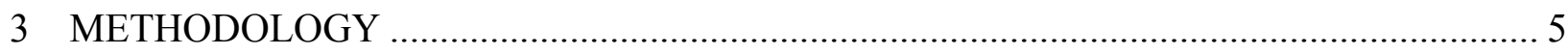

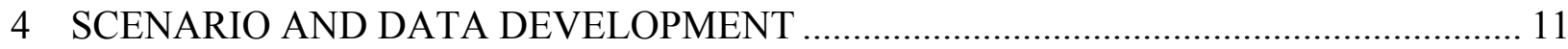

5 RESULTS AND ANALYSES................................................................................. 13

5.1 Changes in Ton-Miles, Energy Use, Upstream Energy Use, and GHG Emissions....... 13

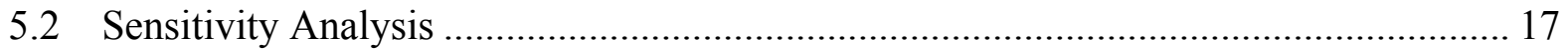

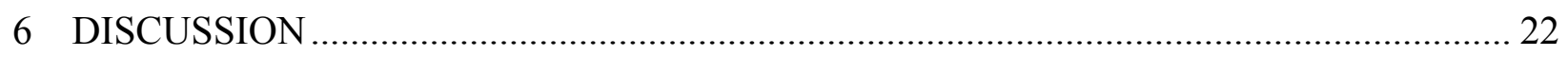

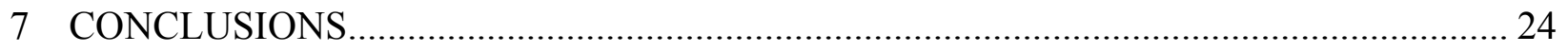

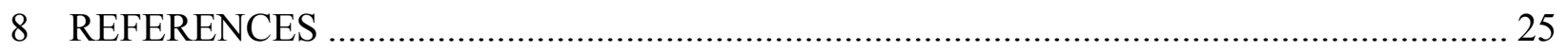

\section{FIGURES}

1 Ton-miles Projection of Each Freight Mode .......................................................... 14

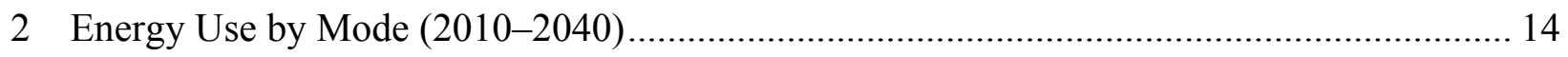

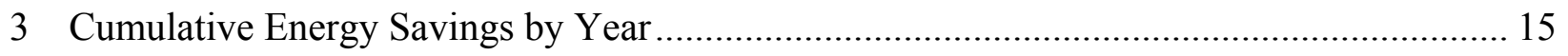

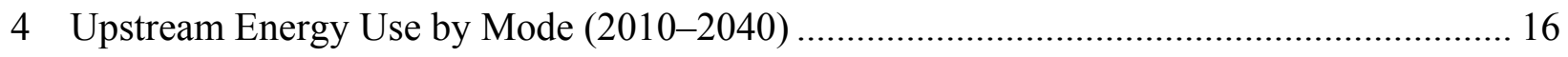

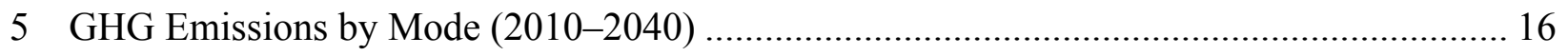

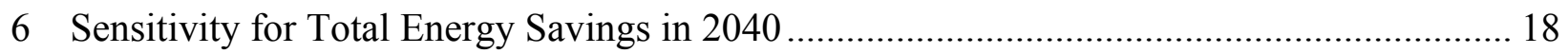

7 Sensitivity for Cumulative Energy Savings (2016-2040) ........................................... 20

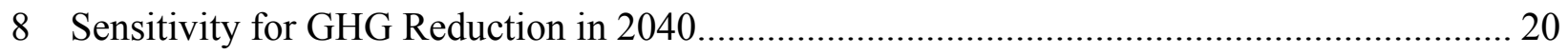

9 Sensitivity for Cumulative GHG Reduction (2016-2040) .......................................... 21 


\section{TABLES}

1 Commodities Selected for Mode Shift Analysis and Potential Shiftable Tonnage (\%) .......... 6

2 Mode Shift Percentage Based on Rail Level of Service ................................................... 7

3 Rail Level of Service Assigned to FAF Zones ......................................................... 7

4 Mode Share (of ton-miles) for Commodities Selected ............................................... 12 


\section{ACKNOWLEDGMENTS}

The authors gratefully acknowledge the sponsorship of the Vehicle Technologies Office (VTO) within the Office of Energy Efficiency and Renewable Energy of the U.S. Department of Energy. The authors thank the VTO project managers Jake Ward and Rachael Nealer for their support and guidance while carrying out the evaluations presented in this report. The authors also thank Dr. James Winebrake for review of a short summary and a PowerPoint ${ }^{\circledR}$ presentation of the methodology and baseline-scenario results. Although others supported, contributed to, or reviewed this research effort, the authors are solely responsible for the contents of this report. 


\section{GENERAL ACRONYMS, INITIALISMS, AND ABBREVIATIONS}

The following is a list of acronyms and abbreviations used in this document. Some acronyms used only in tables may be defined only in those tables.

$\begin{array}{ll}\begin{array}{ll}\text { AEO } \\ \text { Argonne }\end{array} & \begin{array}{l}\text { Annual Energy Outlook } \\ \text { Argonne National Laboratory }\end{array} \\ \text { Btu } & \text { British thermal unit(s) } \\ \text { CFS } & \begin{array}{l}\text { Commodity Flow Survey } \\ \text { carbon dioxide }\end{array} \\ \text { DOE } & \text { U.S. Department of Energy } \\ \text { DOT } & \text { U.S. Department of Transportation } \\ \text { EIA } & \text { Energy Information Administration } \\ \text { FAF } & \text { Freight Analysis Framework } \\ \text { FHWA } & \text { Federal Highway Administration } \\ \text { GHG } & \text { greenhouse gas } \\ \text { GREET } & \text { Greenhouse gas, Regulated Emissions, and Energy use in Transportation } \\ \text { NEAT } & \text { Non-light duty Energy and GHG emissions Accounting Tool } \\ \text { SCTG } & \text { Standard Classification of Transported Goods } \\ \text { TEDB } & \text { Transportation Energy Data Book } \\ \text { VTO } & \text { Vehicle Technologies Office }\end{array}$




\section{AN EVALUATION OF THE POTENTIAL FOR SHIFTING OF FREIGHT FROM TRUCK TO RAIL AND ITS IMPACTS ON ENERGY USE AND GHG EMISSIONS}

\section{INTRODUCTION}

The truck mode is the dominant freight-carrying mode in the U.S., carrying nearly threequarters of the annual tonnage transported (Davis et al. 2016). In addition, except for the aviation mode, truck is the least energy-efficient mode for freight transportation. However, truck's ability to provide door-to-door service without any additional investment in infrastructure makes it a preferred mode for shippers.

The Federal Highway Administration (FHWA), in its Freight Analysis Framework (FAF) version 3.5, projected a $1.56 \%$ average annual growth in truck tonnage between 2015 and 2040 (FHWA 2015). In terms of ton-miles, the rate of growth during the same period was even higher, at $2.19 \%$, which indicated more tonnage carried over longer distances. In its recently released FAF version 4 (FHWA 2016), FHWA projects a 1.22\% average annual growth in truck tonnage and a $1.63 \%$ annual growth in truck ton-miles between 2015 and 2045.

The U.S. Government, through its Department of Energy (DOE), has sponsored projects that reduce dependence on petroleum and reduce emissions of greenhouse gases (GHG). DOE sponsors projects that increase the energy efficiency of various transportation modes, including intercity freight-carrying trucks. The Energy Information Administration (EIA) within DOE accounts for the impacts of such future energy efficiency technologies and projects energy consumption by various transportation modes in its Annual Energy Outlook (AEO). In its 2016 AEO, EIA projected an average annual growth of $0.51 \%$ in heavy (class $7 \& 8$ ) truck energy use between 2015 and 2040 (EIA 2016). This increase contrasts with the projected average annual declines of $0.82 \%$ and $1.31 \%$ in energy use by cars and light trucks, respectively. Heavy trucks are the third-largest energy consumers among highway vehicles, behind light trucks and cars. Although the FAF and AEO projections are not matched exactly, EIA reviews FHWA's FAF projections while developing its AEO projections.

Five modes are used to transport intercity freight in the U.S.: (1) heavy truck, (2) freight rail, (3) marine (water) freight, (4) freight aviation, and (5) pipeline. For the pipeline mode, EIA's transportation energy projections in AEO and historical transportation energy data in the Transportation Energy Data Books published by Oak Ridge National Laboratory cover only the energy consumption by natural gas pipelines. In 2014, the last year for which detailed freight energy consumption data by mode are available, heavy trucks accounted for $67 \%$ of total energy use by freight transportation (Davis et al. 2016). The next largest energy-consuming mode, natural gas pipeline, accounted for $13.5 \%$. In the 2016 AEO, heavy trucks are projected to account for $65.2 \%$ of total energy use by freight modes in 2040 and the next largest energyconsuming mode, natural gas pipeline, is projected to account for 14.6\% (EIA 2016). Thus, heavy trucks consume two-thirds of total energy use by freight transportation modes now and will consume nearly the same share in 2040. 
One option to reduce energy consumption and the resulting GHG emissions from heavy trucks is to shift freight from trucks to a more energy-efficient mode, like rail. Domestic marine, consisting of transport on the Great Lakes, inland waterways, and coastal waterways, is also energy-efficient. However, its infrastructure is limited. In addition, various industries have adopted just-in-time delivery strategies that can be best served by trucks and to some extent by rail.

This report summarizes our evaluation of the potential energy-use and GHG-emissions reduction achieved by shifting freight from truck to rail under a most-likely scenario. A sensitivity analysis is also included. The sensitivity analysis shows changes in energy use and GHG emissions when key parameters are varied. The major contribution and distinction from previous studies is that this study considers the rail level of service (LOS) and commodity movements at the origin-destination (O-D) level. In addition, this study considers the fragility and time sensitivity of each commodity type. 


\section{LITERATURE REVIEW}

Different modes of transportation are used for different types of freight services and commodities. Domestic marine and rail modes are often used for long-distance freight that travels more than 300 miles and for bulk cargo transport services, often when cargo is not timesensitive. These modes are capable of moving large volumes with the least energy use per unit work. Trucks are used for shorter trips, time-sensitive cargo, and delivery to locations where ship and rail infrastructure is not available. Airplanes are typically used for time-sensitive shipments where transportation costs are a small percentage of overall cargo value (Winebrake and Corbett 2010). Energy consumption by freight modes depends on a number of factors, such as type of power plant used by the mode, energy sources, transportation routes, speed, operation (e.g., idling pattern), and logistics. Among the surface transportation modes, truck ranks the highest in energy intensity, about 5 to 8 times greater than rail. Air freight energy intensities are even higher, about 6 to 10 times greater than truck.

Intermodalism and mode-shifting are often looked upon as providing significant opportunities for energy and emissions reduction in the freight transportation sector (Komor 1995; Kreutzberger et al. 2003; NPWI 2004; Patterson et al. 2008; Winebrake et al. 2008). Komor (1995) noted that present trains and trucks do compete in some long-haul markets, and additional savings of up to $0.2-0.5 \mathrm{EJ}$ (0.19-0.47 quad) may possibly be achieved by shifting more long-haul freight from trucks to trains. Kreutzberger et al. (2003) provided a review of studies that analyzed the environmental benefits of intermodal transport in comparison with unimodal road transport. The overview clearly shows that intermodal transport has substantially better environmental performance than unimodal road transport. Winebrake et al. (2008) presented an energy and environmental network analysis model, named Geospatial Intermodal Freight Transport, designed to explore trade-offs among such attributes as time and distance, cost, energy, and emissions for alternative route selection across different freight mode combinations. This study identified cost penalties and emissions penalties for long-haul freight when considering time-of-delivery by route as the main objective through three case studies. However, the case studies were limited to three regional freight movements. In addition, results of such models are very dependent on origin and destination routes, requiring a detailed network for each freight mode. In a follow-up study, Winebrake and Corbett (2010) concluded that freight modal shifts offer large side-by-side benefits in terms of energy consumption and emissions reduction. However, system benefits vary depending on vessel, vehicle, locomotive, and route characteristics and are constrained by compatibility, feasibility, and practicality of mode shift. Practicality includes both infrastructure capability and time sensitivity of different commodity types. Winebrake and Corbett (2010) briefly discussed an IF-TOLD model, which is a framework for considering freight options such as intermodalism/mode-shifting, clean fuels, technology efficiency, best practices in operation, supply chain management and demand (tonmiles). However, their book chapter does not detail the model. Patterson et al. (2008) estimated the potential for $\mathrm{CO}_{2}$ emission reductions in the freight transportation sector by estimating demand for premium-intermodal services for five different categories of shipments between 18 city pairs; this study was based on a stated-preference carrier-choice survey of shippers in the corridor to develop mode-share models. Nealer et al. (2011) developed an input-output analysis, which estimated "total embodied ton-kilometers" across the supply chain of products. Using 
this model, the study of Nealer et al. indicated that targeting the trucking industry and analyzing the trucking share of each industry may suggest that non-road alternative modes of transportation are sufficient, thus reducing traffic congestion on our already crowded roads. 


\section{METHODOLOGY}

We used Argonne's Non-light-duty Energy and GHG Emissions Accounting Tool (NEAT) for our evaluation of the potential energy and GHG emissions impacts of shifting freight from truck to rail. NEAT uses FHWA's FAF projections with some modifications. First, some of FAF's 43 commodities are combined to form 30 groups of commodities. Next, six energy-related sub-commodities are separated from this group and added to form 36 commodities (Vyas 2014). FAF's ton-mile projections are used for non-energy commodities, while EIA's AEO projections are used for energy commodities. NEAT is populated with energy intensity estimates developed at Argonne (Vyas 2014) and with GHG emissions rates from Argonne's Greenhouse gases, Regulated Emissions, and Energy Use in Transportation (GREET) model (https://greet.es.anl.gov/). NEAT develops energy use and GHG emissions estimates by freight mode and fuel type. More information, including documentation and past presentations, is available at http://www.anl.gov/energy-systems/project/neat-non-light-duty-energy-and-ghgemissions-accounting-tool. NEAT is updated periodically with data from the latest available FAF and AEO. For this analysis, we used the 2015 version of NEAT, which reflected FAF version 3.5 (FHWA 2015) and AEO 2015 (EIA 2015).

For evaluating the potential of shifting freight from truck to rail, we first evaluated commodity tonnage originating from FAF zones. FAF 3.5 data (FHWA 2015) were available for 131 zones, of which 123 were domestic zones and eight were external zones. Because two zones in Hawaii did not have any rail service, we eliminated them and analyzed commodity data for the remaining 121 domestic zones. We used three criteria to select the commodities that have the potential to be shifted from truck to rail at the zone level: 1) average originating commodity tonnage, 2) transport distance, and 3) time sensitivity of the commodities. We selected originating commodity tonnage for the year 2040 transported over 300 miles by truck. We first computed the average of originating tonnage from all zones and eliminated two commodities that averaged less than 90,000 tons transported by truck over 300 miles. These commodities were tobacco products $(<12,000$ tons $)$ and crude petroleum. In addition, three commodities - gravel, gasoline, and logs - did not have any tonnage transported over 300 miles by truck. Next, we eliminated commodities that had relatively low originating tonnage. For this elimination, we dropped 16 commodities that originated from fewer than $30 \mathrm{FAF}$ zones (out of 121) and had average originating tonnage of less than 100,000. Very low-tonnage commodities may not shift to rail because railroads tend to allocate rail cars first to large-tonnage shipments, resulting in long waiting times for low-tonnage shipments. Of the remaining 22 commodities, we dropped three time-sensitive and/or delicate commodities. These were meat/seafood, electronics, and precision instruments.

We noted that FAF projects substantial tonnage of these 19 selected commodities being transported over long distances by truck. These projections indirectly reflect historical data, which form the basis for FAF methodology. They also mean that shippers prefer the truck mode over other modes because of either the commodity type or the delivery requirements. That meant that some commodities could not be shifted $100 \%$ to rail even where good rail service existed between an O-D pair. We used technical judgment to assign a potential mode shift percentage to each commodity. Table 1 lists the commodities selected and the potential mode-shift tonnage 
TABLE 1 Commodities Selected for Mode Shift Analysis and Potential Shiftable Tonnage (\%)

\begin{tabular}{|c|c|c|}
\hline $\begin{array}{c}\text { SCTG } \\
\text { Code }\end{array}$ & Commodity & $\begin{array}{c}\% \text { of Tonnage } \\
\text { That Can Be } \\
\text { Shifted }\end{array}$ \\
\hline 03 & Other agricultural products & 30 \\
\hline 06 & Milled grain products & 50 \\
\hline 07 & Other foodstuffs & 50 \\
\hline 14 & Metallic ores & 100 \\
\hline 20 & Basic chemicals & 30 \\
\hline 21 & Pharmaceuticals & 50 \\
\hline 23 & Chemical products & 50 \\
\hline 24 & Plastics and rubber & 100 \\
\hline 27 & Newsprint and paper & 100 \\
\hline 28 & Paper articles & 100 \\
\hline 29 & Printed products & 50 \\
\hline 30 & Textile/leather & 100 \\
\hline 32 & Base metals & 100 \\
\hline 33 & Articles of base metal & 100 \\
\hline 34 & Machinery & 100 \\
\hline 36 & Motorized vehicles & 50 \\
\hline 37 & Transportation equipment & 100 \\
\hline 39 & Furniture & 30 \\
\hline 40 & Miscellaneous manufacturing products & 80 \\
\hline
\end{tabular}

percentage assigned. The standard classification of transported goods (SCTG) codes are described in a publication (CFS 2006).

We also evaluated the availability of rail service in FAF zones. Each FAF zone received one of the five rail-LOS assignments in accordance with our evaluation of the current rail service, including quality of infrastructure, capacity, and frequency of service. The five levels of service were (1) excellent, (2) good, (3) moderate, (4) poor, and (5) none. We evaluated each O-D pair and assigned the pair a rail LOS that was the lower of the values at the origin and destination. For example, if the origin of an O-D pair had an excellent rail LOS and the destination had a moderate rail LOS, the O-D pair was assigned a moderate rail LOS. Because "poor" and "none" levels of rail service would not offer better service than the truck mode, we assigned zero potential for mode shift to such O-D pairs. In addition, because truck mode is the preferred mode in FAF projections, we assigned less than $100 \%$ mode shift potential in accordance with the rail LOS between O-D pairs. Table 2 lists our assigned potentials for mode shift based on rail LOS. 
TABLE 2 Mode Shift Percentage Based on Rail

Level of Service

\begin{tabular}{cc}
\hline $\begin{array}{c}\text { Rail Level of Service } \\
\text { Between O-D Pair }\end{array}$ & $\begin{array}{c}\text { \% of Tonnage } \\
\text { Shifted to Rail }\end{array}$ \\
\hline Excellent & 66 \\
Good & 30 \\
Moderate & 10 \\
\hline
\end{tabular}

For the rail-LOS assignment, we assumed that railroads would continue to serve the areas they serve currently and all their infrastructure improvements would maintain the current LOS. In addition, we assumed that railroads would have enough capacity to handle the additional tonnage shifted as a result of our analysis. Table 3 shows the rail LOS assigned to each FAF zone.

TABLE 3 Rail Level of Service Assigned to FAF Zones*

\begin{tabular}{cll}
\hline FAF & & \multicolumn{1}{c}{ FAF Zone Name } \\
Zone \# & & \multicolumn{1}{c}{ Rail Level of } \\
\hline & Service \\
\hline 11 & Birmingham-Hoover-Cullman, AL CSA & Excellent \\
012 & Mobile-Daphne-Fairhope, AL CSA & Excellent \\
019 & Remainder of Alabama & Good \\
020 & Alaska & Poor \\
041 & Phoenix-Mesa-Scottsdale, AZ MSA & Moderate \\
042 & Tucson, AZ MSA & Good \\
049 & Remainder of Arizona & Moderate \\
050 & Arkansas & Good \\
061 & Los Angeles-Long Beach-Riverside, CA CSA & Excellent \\
062 & Sacramento--Arden-Arcade--Truckee, CA-NV CSA (CA Part) & Good \\
063 & San Diego-Carlsbad-San Marcos, CA MSA & Moderate \\
064 & San Jose-San Francisco-Oakland, CA CSA & Good \\
069 & Remainder of California & Excellent \\
081 & Denver-Aurora-Boulder, CO CSA & Excellent \\
089 & Remainder of Colorado & Moderate \\
091 & Hartford-West Hartford-Willimantic, CT CSA & Excellent \\
092 & New York-Newark-Bridgeport, NY-NJ-CT-PA CSA (CT Part) & Excellent \\
099 & Remainder of Connecticut & Good \\
100 & Delaware & Moderate \\
111 & Washington-Arlington-Alexandria, DC-VA-MD-WV MSA (DC Part) & Excellent \\
121 & Jacksonville, FL MSA & Excellent \\
122 & Miami-Fort Lauderdale-Pompano Beach, FL MSA & Good \\
123 & Orlando-Deltona-Daytona Beach, FL CSA & Excellent \\
& &
\end{tabular}


TABLE 3 (Cont.)

\begin{tabular}{|c|c|c|}
\hline $\begin{array}{c}\text { FAF } \\
\text { Zone \# }\end{array}$ & FAF Zone Name & $\begin{array}{c}\text { Rail Level of } \\
\text { Service }\end{array}$ \\
\hline 124 & Tampa-St. Petersburg-Clearwater, FL MSA & Good \\
\hline 129 & Remainder of Florida & Good \\
\hline 131 & Atlanta-Sandy Springs-Gainesville, GA-AL CSA (GA Part) & Excellent \\
\hline 132 & Savannah-Hinesville-Fort Stewart, GA CSA & Good \\
\hline 139 & Remainder of Georgia & Excellent \\
\hline 151 & Honolulu, HI MSA & None \\
\hline 159 & Remainder of Hawaii & None \\
\hline 160 & Idaho & Moderate \\
\hline 171 & Chicago-Naperville-Michigan City, IL-IN-WI CSA (IL Part) & Excellent \\
\hline 172 & St. Louis-St. Charles-Farmington, MO-IL CSA (IL Part) & Excellent \\
\hline 179 & Remainder of Illinois & Excellent \\
\hline 181 & Chicago-Naperville-Michigan City, IL-IN-WI CSA (IN Part) & Good \\
\hline 182 & Indianapolis-Anderson-Columbus, IN CSA & Excellent \\
\hline 189 & Remainder of Indiana & Good \\
\hline 190 & Iowa & Good \\
\hline 201 & Kansas City-Overland Park-Kansas City, MO-KS CSA (KS Part) & Excellent \\
\hline 209 & Remainder of Kansas & Good \\
\hline 211 & Louisville/Jefferson County-Elizabethtown-Scottsburg, KY-IN CSA (KY Part) & Excellent \\
\hline 219 & Remainder of Kentucky & Good \\
\hline 221 & Baton Rouge-Pierre Part, LA CSA & Excellent \\
\hline 222 & Lake Charles-Jennings, LA CSA & Good \\
\hline 223 & New Orleans-Metairie-Bogalusa, LA CSA & Excellent \\
\hline 229 & Remainder of Louisiana & Good \\
\hline 230 & Maine & Moderate \\
\hline 241 & Baltimore-Towson, MD MSA & Excellent \\
\hline 242 & Washington-Arlington-Alexandria, DC-VA-MD-WV MSA (MD Part) & Good \\
\hline 249 & Remainder of Maryland & Good \\
\hline 251 & Boston-Worcester-Manchester, MA-NH CSA (MA Part) & Good \\
\hline 259 & Remainder of Massachusetts & Good \\
\hline 261 & Detroit-Warren-Flint, MI CSA & Excellent \\
\hline 262 & Grand Rapids-Muskegon-Holland, MI CSA & Good \\
\hline 269 & Remainder of Michigan & Good \\
\hline 271 & Minneapolis-St. Paul-St. Cloud, MN-WI CSA (MN Part) & Excellent \\
\hline 279 & Remainder of Minnesota & Good \\
\hline 280 & Mississippi & Good \\
\hline 291 & Kansas City-Overland Park-Kansas City, MO-KS CSA (MO Part) & Excellent \\
\hline 292 & St. Louis-St. Charles-Farmington, MO-IL CSA (MO Part) & Excellent \\
\hline 299 & Remainder of Missouri & Good \\
\hline 300 & Montana & Moderate \\
\hline 310 & Nebraska & Good \\
\hline 321 & Las Vegas-Paradise-Pahrump, NV CSA & Poor \\
\hline
\end{tabular}


TABLE 3 (Cont.)

\begin{tabular}{|c|c|c|}
\hline $\begin{array}{c}\text { FAF } \\
\text { Zone \# }\end{array}$ & FAF Zone Name & $\begin{array}{c}\text { Rail Level of } \\
\text { Service }\end{array}$ \\
\hline 329 & Remainder of Nevada & Moderate \\
\hline 330 & New Hampshire & Poor \\
\hline 341 & New York-Newark-Bridgeport, NY-NJ-CT-PA CSA (NJ Part) & Excellent \\
\hline 342 & Philadelphia-Camden-Vineland, PA-NJ-DE-MD CSA (NJ Part) & Excellent \\
\hline 349 & Remainder of New Jersey & Moderate \\
\hline 350 & New Mexico & Moderate \\
\hline 361 & Albany-Schenectady-Amsterdam, NY CSA & Excellent \\
\hline 362 & Buffalo-Niagara-Cattaraugus, NY CSA & Good \\
\hline 363 & New York-Newark-Bridgeport, NY-NJ-CT-PA CSA (NY Part) & Excellent \\
\hline 364 & Rochester-Batavia-Seneca Falls, NY CSA & Good \\
\hline 369 & Remainder of New York & Moderate \\
\hline 371 & Charlotte-Gastonia-Salisbury, NC-SC CSA (NC Part) & Excellent \\
\hline 372 & Greensboro--Winston-Salem--High Point, NC CSA & Excellent \\
\hline 373 & Raleigh-Durham-Cary, NC CSA & Good \\
\hline 379 & Remainder of North Carolina & Good \\
\hline 380 & North Dakota & Excellent \\
\hline 391 & Cincinnati-Middletown-Wilmington, OH-KY-IN CSA (OH Part) & Excellent \\
\hline 392 & Cleveland-Akron-Elyria, OH CSA & Excellent \\
\hline 393 & Columbus-Marion-Chillicothe, OH CSA & Good \\
\hline 394 & Dayton-Springfield-Greenville, OH CSA & Moderate \\
\hline 399 & Remainder of Ohio & Excellent \\
\hline 401 & Oklahoma City-Shawnee, OK CSA & Moderate \\
\hline 402 & Tulsa-Bartlesville, OK CSA & Moderate \\
\hline 409 & Remainder of Oklahoma & Moderate \\
\hline 411 & Portland-Vancouver-Beaverton, OR-WA MSA (OR Part) & Excellent \\
\hline 419 & Remainder of Oregon & Moderate \\
\hline 421 & Philadelphia-Camden-Vineland, PA-NJ-DE-MD CSA (PA Part) & Excellent \\
\hline 422 & Pittsburgh-New Castle, PA CSA & Excellent \\
\hline 429 & Remainder of Pennsylvania & Good \\
\hline 440 & Rhode Island & Good \\
\hline 451 & Charleston-North Charleston-Summerville, SC MSA & Good \\
\hline 452 & Greenville-Spartanburg-Anderson, SC CSA & Good \\
\hline 459 & Remainder of South Carolina & Good \\
\hline 460 & South Dakota & Poor \\
\hline 471 & Memphis, TN-MS-AR MSA (TN Part) & Excellent \\
\hline 472 & Nashville-Davidson--Murfreesboro--Columbia, TN CSA & Good \\
\hline 479 & Remainder of Tennessee & Moderate \\
\hline 481 & Austin-Round Rock, TX MSA & Good \\
\hline 482 & Beaumont-Port Arthur, TX MSA & Good \\
\hline 483 & Corpus Christi-Kingsville, TX CSA & Moderate \\
\hline 484 & Dallas-Fort Worth, TX CSA & Excellent \\
\hline
\end{tabular}


TABLE 3 (Cont.)

\begin{tabular}{cll}
\hline FAF & & \multicolumn{1}{c}{ Fail Level of } \\
Zone \# & & Service \\
\hline & & Good \\
485 & El Paso, TX MSA & Excellent \\
486 & Houston-Baytown-Huntsville, TX CSA & Moderate \\
487 & Laredo, TX MSA & Excellent \\
488 & San Antonio, TX MSA & Good \\
489 & Remainder of Texas & Excellent \\
491 & Salt Lake City-Ogden-Clearfield, UT CSA & Moderate \\
499 & Remainder of Utah & Moderate \\
500 & Vermont & Excellent \\
511 & Richmond, VA MSA & Excellent \\
512 & Virginia Beach-Norfolk-Newport News, VA-NC MSA (VA Part) & Good \\
513 & Washington-Baltimore-Northern Virginia, DC-MD-VA-WV CSA (VA Part) & Excellent \\
519 & Remainder of Virginia & Excellent \\
531 & Seattle-Tacoma-Olympia, WA CSA & Excellent \\
539 & Remainder of Washington & Moderate \\
540 & West Virginia & Excellent \\
551 & Milwaukee-Racine-Waukesha, WI CSA & Good \\
559 & Remainder of Wisconsin & Good \\
560 & Wyoming &
\end{tabular}

*MSA $=$ Metropolitan Statistical Area; CSA = Combined Statistical Area 


\section{SCENARIO AND DATA DEVELOPMENT}

We developed a baseline scenario with a minimum tonnage criterion, to select O-D pairs within a commodity for further analysis. The specific minimum tonnage requirement for an O-D pair to be selected within a commodity was 10,000 tons. Any lesser tonnage was deemed as not attractive enough to induce the shippers to choose the rail mode over truck. Each O-D pair was evaluated for commodities listed in Table 1, and pairs that met the minimum tonnage criterion specific to the baseline scenario were selected. This selection process provided an O-D matrix for each commodity. These matrices contained tonnage transported by truck over 300 miles that met the minimum tonnage requirement.

Next, we estimated implied average length of haul (LOH) for the truck mode between each selected O-D pair. We applied the factors in Tables 1 and 2 to arrive at the tonnage that would be shifted to rail. All the selected O-D pairs had rail shipments that were used to estimate implied average $\mathrm{LOH}$ by rail. This provided us with estimates of truck ton-miles that would be shifted to rail for each commodity and the resulting rail ton-miles. This step helped us develop preliminary ton-mile inputs necessary for NEAT. Truck and rail ton-miles by commodity for each selected O-D pair are estimated using the following equations:

Truck ton-miles (scenario case) $=$ Truck ton-miles (base case) $-\mathrm{LOH}_{\text {truck }}$ *shifted tons; Rail ton-miles (scenario case) $=$ Rail ton-miles (base case) $+\mathrm{LOH}_{\text {rail }}{ }^{*}$ shifted tons .

As explained earlier, many FAF commodities are combined to form commodity groups for NEAT. We developed ton-mile estimates by mode for each commodity group resulting from reductions in truck ton-miles and increases in rail ton-miles. By using these new estimates, we revised total ton-miles and mode share inputs for NEAT. Table 4 shows the truck and rail mode share of ton-miles for each selected commodity in the base case and the baseline scenario case. 
TABLE 4 Mode Share (of ton-miles) for Commodities Selected

\begin{tabular}{|c|c|c|c|c|c|c|c|c|c|}
\hline \multirow[b]{2}{*}{$\begin{array}{c}\text { SCTG } \\
\text { Code }\end{array}$} & \multirow[b]{2}{*}{ Commodity } & \multicolumn{2}{|c|}{2025 Base Case } & \multicolumn{2}{|c|}{2025 Scenario } & \multicolumn{2}{|c|}{2040 Base Case } & \multicolumn{2}{|c|}{2040 Scenario } \\
\hline & & Truck & Rail & Truck & Rail & Truck & Rail & Truck & Rail \\
\hline 03 & Other agricultural products & $62.08 \%$ & $12.22 \%$ & $56.48 \%$ & $19.66 \%$ & $62.74 \%$ & $10.80 \%$ & $56.62 \%$ & $19.29 \%$ \\
\hline 06 & Milled grain products & $75.04 \%$ & $24.34 \%$ & $65.03 \%$ & $34.43 \%$ & $75.43 \%$ & $23.81 \%$ & $64.91 \%$ & $34.45 \%$ \\
\hline 07 & Other foodstuffs & $75.38 \%$ & $24.06 \%$ & $65.59 \%$ & $33.90 \%$ & $74.98 \%$ & $24.46 \%$ & $65.08 \%$ & $34.42 \%$ \\
\hline 14 & Metallic ores & $12.69 \%$ & $54.38 \%$ & $10.77 \%$ & $56.52 \%$ & $11.71 \%$ & $56.58 \%$ & $9.64 \%$ & $58.86 \%$ \\
\hline 20 & Basic chemicals & $40.79 \%$ & $48.47 \%$ & $37.12 \%$ & $52.21 \%$ & $44.98 \%$ & $46.89 \%$ & $40.41 \%$ & $51.54 \%$ \\
\hline 21 & Pharmaceuticals & $83.61 \%$ & $11.90 \%$ & $78.09 \%$ & $18.03 \%$ & $83.97 \%$ & $11.58 \%$ & $76.29 \%$ & $19.83 \%$ \\
\hline 23 & Chemical products & $78.03 \%$ & $19.94 \%$ & $67.45 \%$ & $30.77 \%$ & $77.76 \%$ & $20.10 \%$ & $66.60 \%$ & $31.51 \%$ \\
\hline 24 & Plastics and rubber & $64.61 \%$ & $34.92 \%$ & $47.42 \%$ & $52.16 \%$ & $64.67 \%$ & $34.85 \%$ & $46.58 \%$ & $52.98 \%$ \\
\hline 27 & Newsprint and paper & $53.06 \%$ & $46.02 \%$ & $41.33 \%$ & $57.87 \%$ & $52.31 \%$ & $46.66 \%$ & $40.50 \%$ & $58.61 \%$ \\
\hline 28 & Paper articles & $75.90 \%$ & $23.71 \%$ & $61.97 \%$ & $37.66 \%$ & $75.62 \%$ & $23.90 \%$ & $60.74 \%$ & $38.79 \%$ \\
\hline 29 & Printed products & $90.23 \%$ & $8.72 \%$ & $82.49 \%$ & $16.47 \%$ & $89.83 \%$ & $8.91 \%$ & $80.95 \%$ & $17.80 \%$ \\
\hline 30 & Textile/leather & $82.57 \%$ & $15.69 \%$ & $60.59 \%$ & $37.74 \%$ & $81.75 \%$ & $16.31 \%$ & $59.81 \%$ & $38.37 \%$ \\
\hline 32 & Base metals & $65.32 \%$ & $31.29 \%$ & $49.37 \%$ & $47.60 \%$ & $65.33 \%$ & $31.25 \%$ & $48.57 \%$ & $48.35 \%$ \\
\hline 33 & Articles of base metal & $77.96 \%$ & $21.13 \%$ & $59.14 \%$ & $40.08 \%$ & $75.37 \%$ & $23.65 \%$ & $55.40 \%$ & $43.74 \%$ \\
\hline 34 & Machinery & $79.96 \%$ & $16.92 \%$ & $57.99 \%$ & $38.98 \%$ & $78.56 \%$ & $18.09 \%$ & $55.34 \%$ & $41.41 \%$ \\
\hline 36 & Motorized vehicles & $66.93 \%$ & $32.56 \%$ & $58.34 \%$ & $41.16 \%$ & $67.17 \%$ & $32.36 \%$ & $58.30 \%$ & $41.24 \%$ \\
\hline 37 & Transportation equipment & $57.67 \%$ & $38.93 \%$ & $49.88 \%$ & $46.76 \%$ & $56.10 \%$ & $40.40 \%$ & $47.16 \%$ & $49.39 \%$ \\
\hline 39 & Furniture & $85.37 \%$ & $14.21 \%$ & $78.48 \%$ & $21.15 \%$ & $83.56 \%$ & $15.98 \%$ & $76.08 \%$ & $23.52 \%$ \\
\hline 40 & $\begin{array}{l}\text { Miscellaneous manufacturing } \\
\text { products }\end{array}$ & $84.45 \%$ & $14.31 \%$ & $68.79 \%$ & $30.29 \%$ & $84.73 \%$ & $14.08 \%$ & $67.43 \%$ & $31.69 \%$ \\
\hline
\end{tabular}




\section{RESULTS AND ANALYSES}

In this section, we present our results on the impact of mode shift on five aspects: (1) ton-miles, (2) energy consumption, (3) cumulative energy savings, (4) upstream energy consumption, and (5) GHG emissions.

\subsection{CHANGES IN TON-MILES, ENERGY USE, UPSTREAM ENERGY USE, AND GHG EMISSIONS}

The base case in this study is what we derived from AEO 2015 and FAF 3.5 as described earlier. To the extent possible, the NEAT base case reflects data from FAF projections and EIA's AEO projections. However, there are differences. First, both the FAF 3.5 and AEO 2015 projections are only to 2040. In NEAT, projections are made to 2050 by using growth rates derived from the two projections. Second, the FAF projections include ton-miles by multiple modes and unknown/other modes. Analysts at Argonne developed a methodology to allocate these ton-miles to five known modes. Third, neither FAF nor AEO provides commodity-level energy intensities. Commodity- and mode-level energy intensities were developed at Argonne from historical and survey data (Vyas 2014). These values were adjusted so that total modal energy use matches the known data in the Transportation Energy Data Books published by Oak Ridge National Laboratory. Future energy intensities reflect improvements projected in the AEO for each mode. Fourth, neither FAF nor AEO estimates full-fuel-cycle GHG emissions or upstream energy consumption for freight modes. To generate such estimates, NEAT uses feedstock, fuel production, and exhaust GHG emissions and upstream energy use rates from Argonne National Laboratory's GREET model.

Figure 1 shows the change in ton-miles resulting from shifting freight from truck to rail under the baseline scenario (10,000 tons) compared to the NEAT's base case. The change is shown in the form of a small wedge between truck and rail ton-miles. Mode shift from truck to rail reduces total ton-miles by $4.1 \%$ owing to the shift away from truck, and increases total tonmiles by $4.4 \%$ owing to the shift to rail, resulting in an overall increase of $0.3 \%$ in total tonmiles in 2040 . The reason for this $0.3 \%$ increase is that even though the total freight tonnage did not change, transporting freight by rail, on average, resulted in a longer LOH than truck between the same origin and destination.

This small increase in total ton-miles would not imply an increase in total energy consumption because rail mode is much more energy-efficient than truck mode. Figure 2 shows the total energy use by mode in our baseline scenario as well as the changes from the base case. The higher energy efficiency of rail mode resulted in a 1.7\% increase in total energy use in 2040, even though the mode shift caused a $4.4 \%$ increase in total ton-miles because of the shift to rail. Relatively, the $4.1 \%$ decrease in total ton-miles due to the shift away from truck in 2040 resulted in a $6.0 \%$ reduction in total energy use. The net effect was a $4.3 \%$ reduction in total freight energy use. 


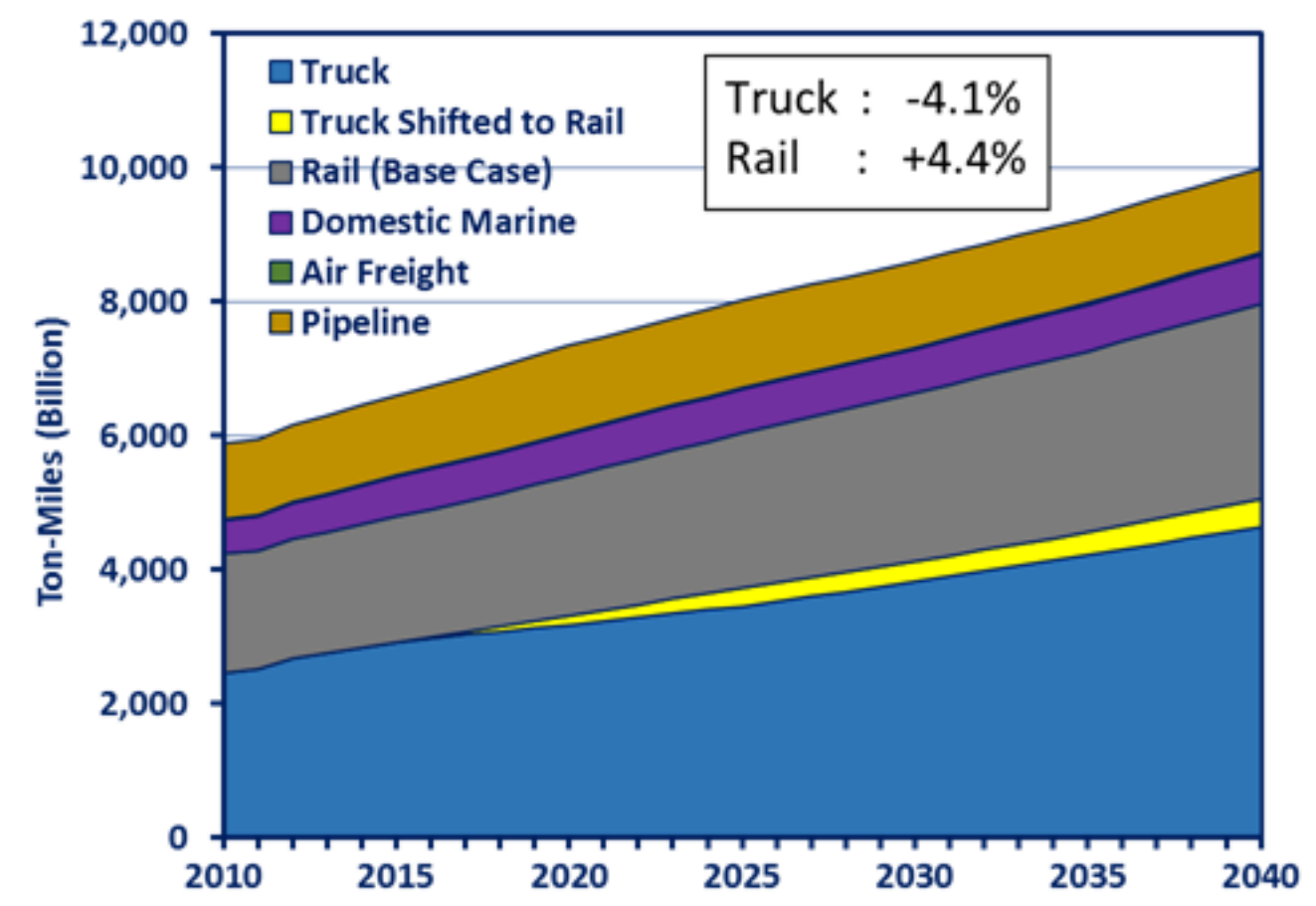

FIGURE 1 Ton-miles Projection of Each Freight Mode

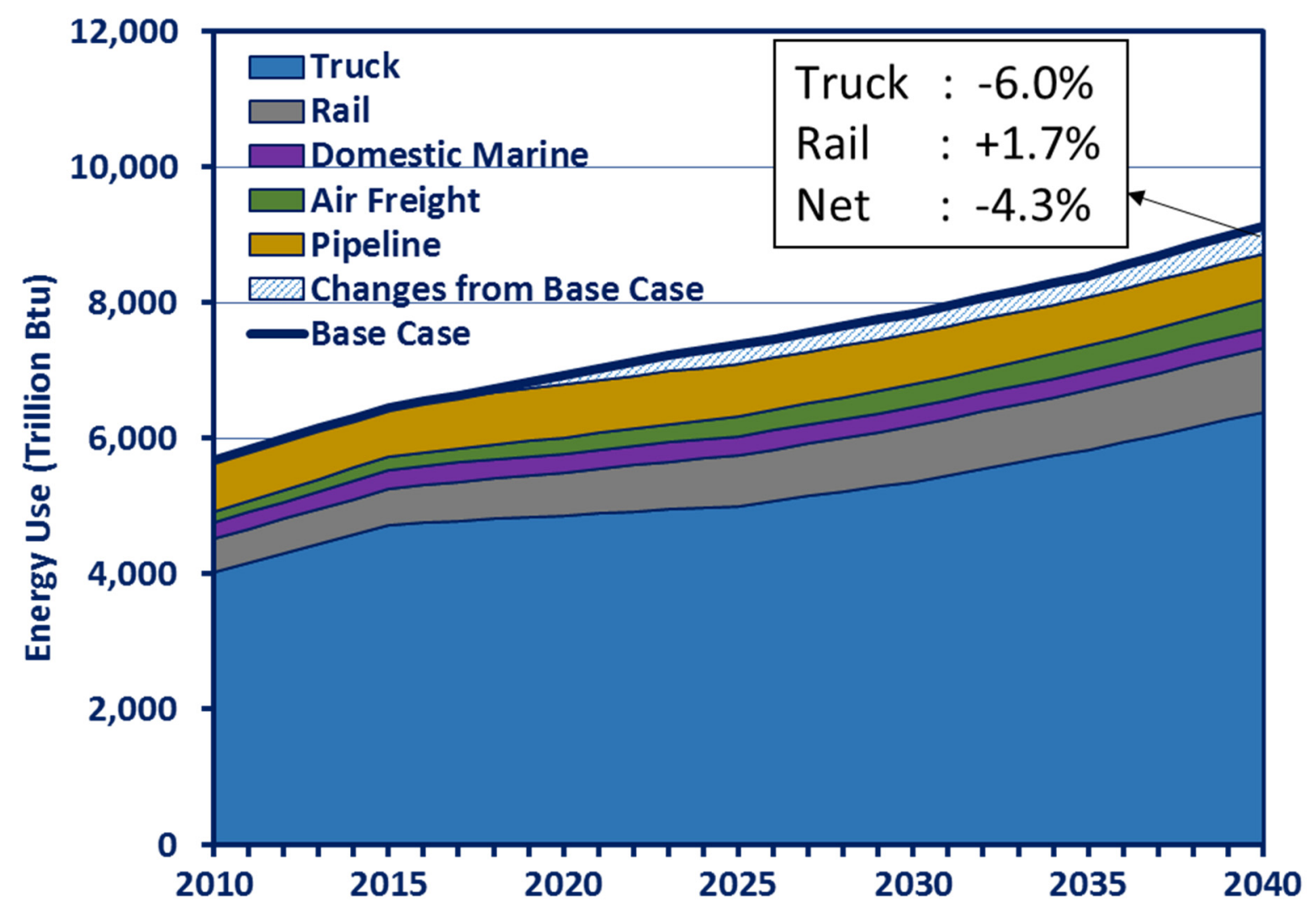

FIGURE 2 Energy Use by Mode (2010-2040) 
Figure 3 shows cumulative energy savings by year due to the mode shift from truck to rail. The Figure shows that the energy savings rise sharply after relatively small increases during the initial years. This is because we have assumed a linear change in ton-miles between 2018 and 2025. The cumulative energy savings are only 1,475 trillion Btu by 2025 , but rise to 6,350 trillion Btu by 2040.

The use of bio-fuels by the truck mode affects upstream energy use significantly. The truck mode uses bio-diesel blends, while rail mode uses only petroleum diesel. From Figure 4, we observe a slightly larger total upstream energy reduction brought about by a modal shift: a $6.3 \%$ reduction in total upstream energy use attributed to truck and a $1.5 \%$ increase in total upstream energy use attributed to rail, which leads to about a $4.9 \%$ net reduction in total upstream energy use ${ }^{1}$. The larger upstream energy reduction (4.9\% compared to the $4.3 \%$ reduction in end-use energy) occurs because trucks would use less bio-diesel as a result of the mode shift. Bio-diesel is a significant contributor to upstream energy consumption.

The reduction in total energy and upstream energy usage leads to a similar magnitude of reduction in total GHG emissions, as shown in Figure 5. Total GHG emissions would be reduced by $4.4 \%$ by 2040 , combining a reduction of $6 \%$ from truck and an increase of $1.6 \%$ from rail.

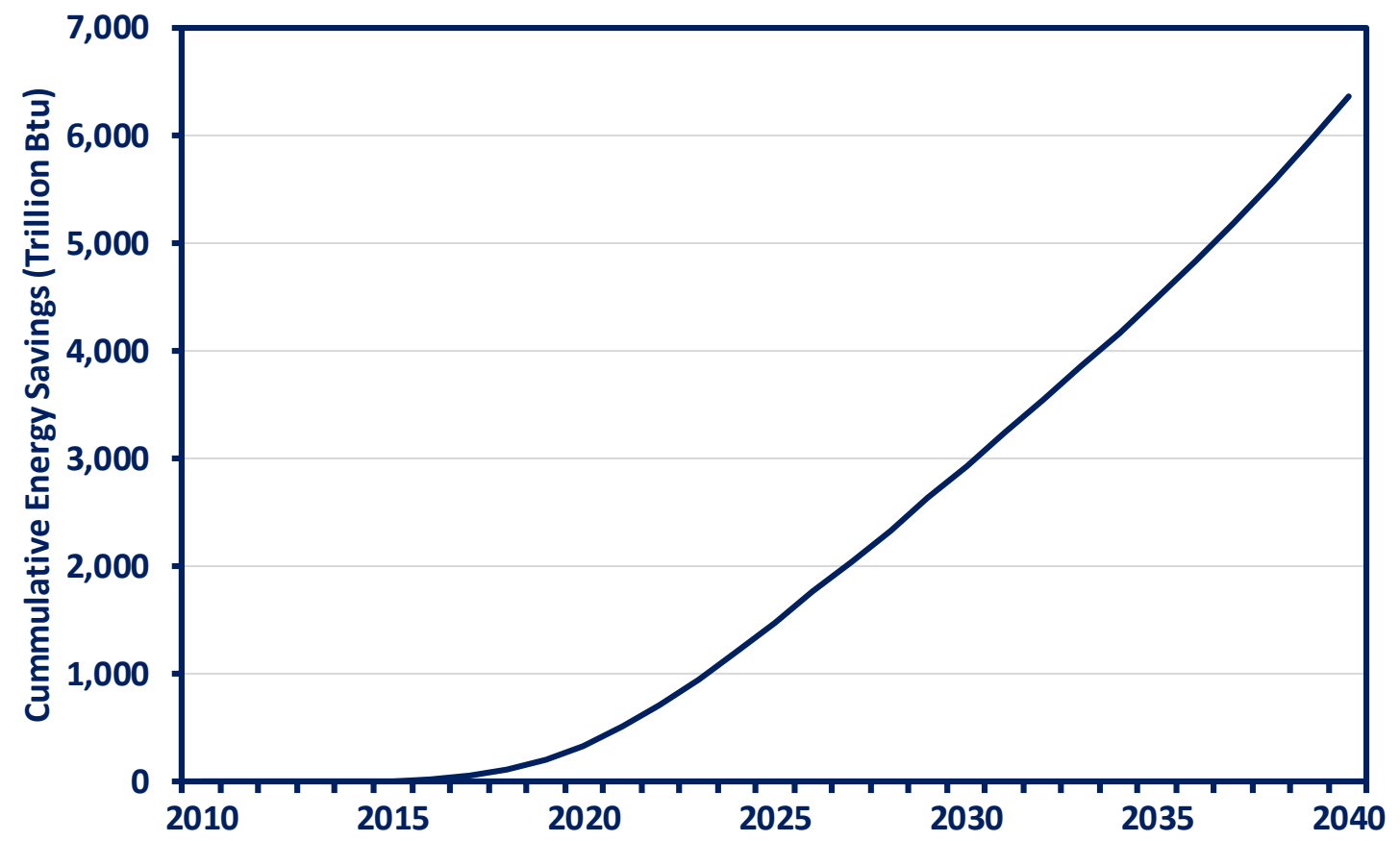

FIGURE 3 Cumulative Energy Savings by Year

\footnotetext{
${ }^{1}$ Calculation contains a rounding error of $+/-0.1$.
} 


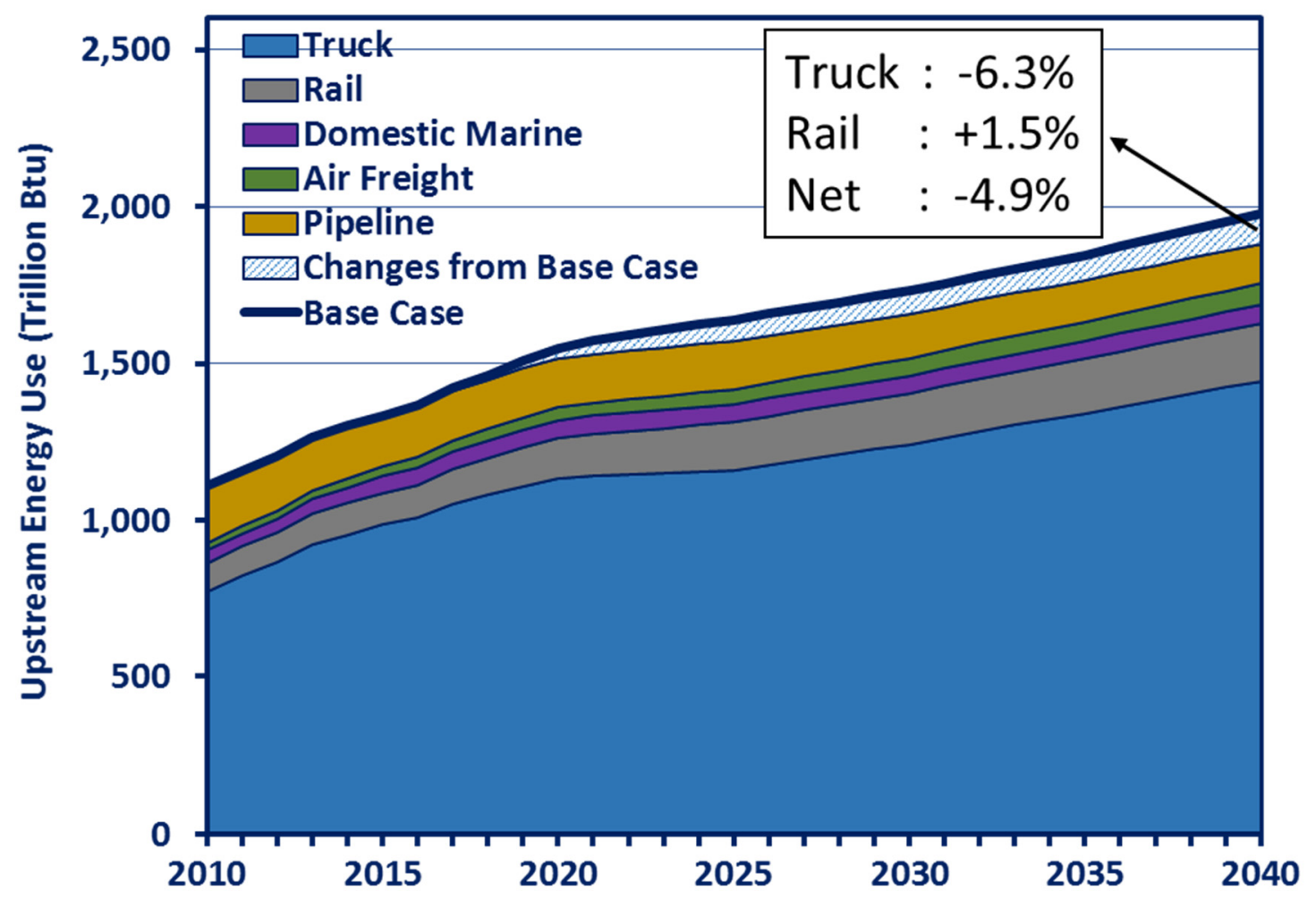

FIGURE 4 Upstream Energy Use by Mode (2010-2040)

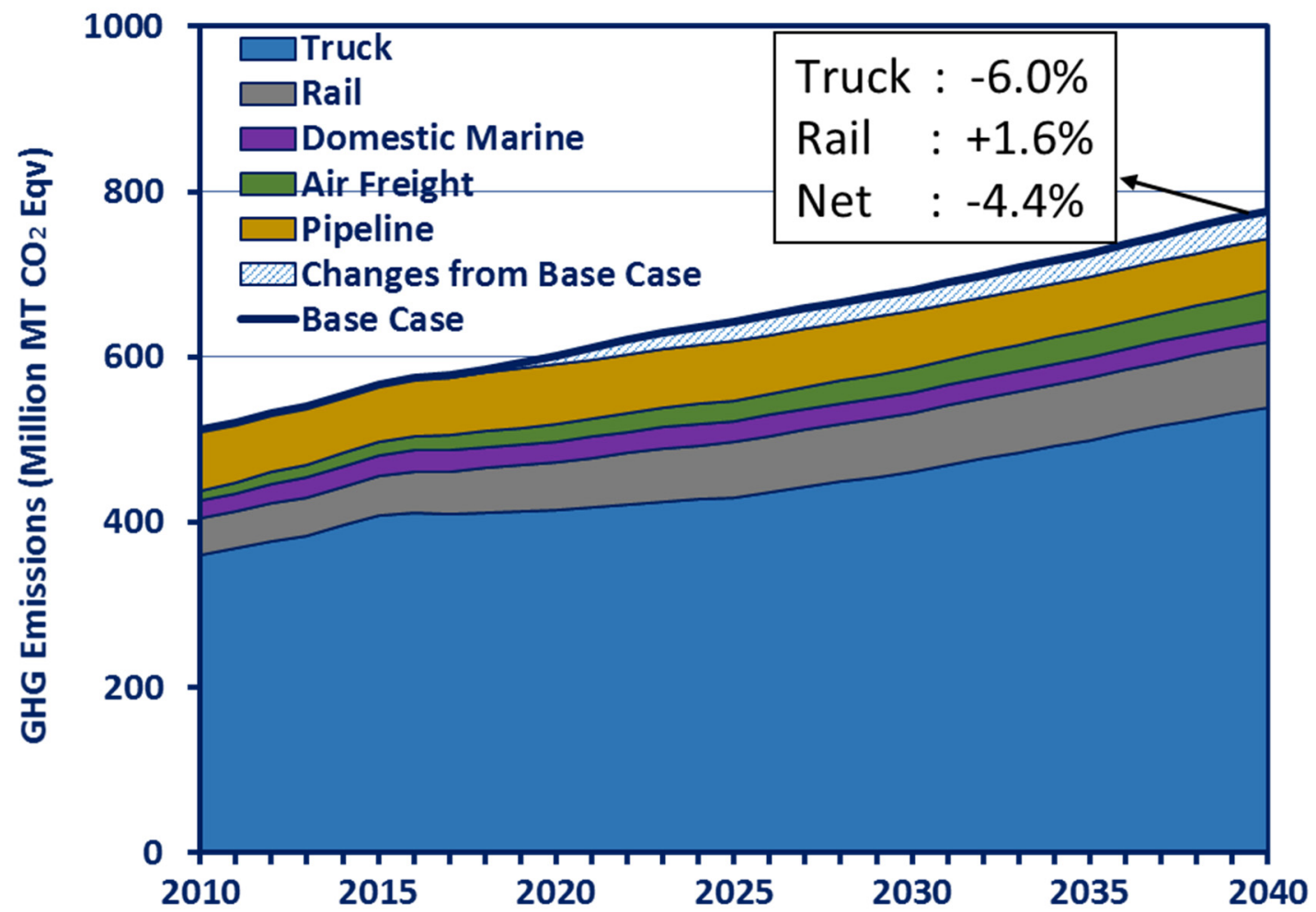

FIGURE 5 GHG Emissions by Mode (2010-2040) 


\subsection{SENSITIVITY ANALYSIS}

Sensitivity analyses play a crucial role in assessing the robustness of the findings and the impacts of changes in key assumptions or parameters. The baseline scenario detailed so far is dependent on several assumptions. These assumptions resulted in fixed values or limits on key parameters and provided the baseline scenario results. However, all our baseline-scenario assumptions could have a range of values. Sensitivity analysis would allow us to estimate the results with different values of key parameters.

Our key assumptions for the baseline scenario included mode shift potential for each rail LOS, the percent of tonnage of a commodity that can be shifted from truck to rail, the truck $\mathrm{LOH}$ for selecting an O-D pair, and the minimum tonnage for selecting an O-D pair. We conducted the sensitivity analysis by changing each of these input parameters individually by $+/-50 \%$ of the values used in the baseline scenario. Note that we refer to the above-described analysis as the baseline scenario in this section. The following four parameters were changed:

1. LOS-based mode shift percentage, in accordance with the rail LOS between an O-D pair (the baseline-scenario values are shown in Table 2). The potential for mode shift from truck to rail under the sensitivity analysis ranged from $99 \%$ to $33 \%$ for an excellent LOS, $45 \%$ to $15 \%$ for a good LOS, and $15 \%$ to $5 \%$ for a moderate LOS.

2. Commodity level percentage of tons that can be shifted, which is based on commodity type. Table 1 gives the baseline-scenario values, which ranged from $30 \%$ to $100 \%$. We varied mode shift percentage for each commodity by $+/-50 \%$, making sure that the values remained less than or equal to $100 \%$ and greater than or equal to $0 \%$.

3. The minimum $\mathbf{L O H}$ of a truck shipment that can be considered for mode shift, selecting truck LOHs of 150 and 450 miles (the baseline-scenario value is 300 miles).

4. The minimum tonnage required between an O-D pair to make it a candidate for mode shift. The baseline-scenario value of 10,000 tons was varied from 5,000 to 15,000 tons.

Results of the sensitivity analysis are presented in Figures 6 to 9. The vertical line in Figures 6 to 9 represents the baseline scenario. The orange bars show changes relative to the baseline resulting from $+50 \%$ values of the parameters, while the blue bars show changes resulting from $-50 \%$ values of the parameters. Each result is shown both as actual-value deviation from the baseline and percentage deviation from the baseline.

The first group (top two bars) in the figures shows the combined effect of parameters 1 and 2. We vary percent tons shifted depending on both rail LOS and commodity type (shown as "Comm" in the figures) by $+/-50 \%$ of the baseline-scenario values. For example, the percent of potential mode shift due to rail LOS, under the $+50 \%$ case, increases to $99 \%, 45 \%$ and $15 \%$ for Excellent, Good and Moderate, respectively. Simultaneously, the percent of potential mode shift of tons for each selected commodity was increased/decreased by $50 \%$, where possible. For example, under the $+50 \%$ case, the value for milled grain products would be $75 \%$, but the value for metallic ores will remain unchanged at $100 \%$. The second and third groups (from the top) in 
the figures look at the effects of percent shifted by rail LOS and percent shifted depending on commodity types individually. The next two sets of bars show the effect of varying minimum $\mathrm{LOH}$ for truck, and the bottom two bars show the effect of varying minimum tonnage for selecting an $\mathrm{O}-\mathrm{D}$ pair.

Figure 6 shows the results, in terms of total energy change relative to the baseline scenario in 2040, of varying the parameters as explained above. The combined effects of varying percent shifted on the basis of rail LOS and commodity type range from -303 trillion Btu (less savings) for the $-50 \%$ case to +312 trillion Btu for the $+50 \%$ case. The $+50 \%$ case provides $7.8 \%$ total energy savings, 3.4\% more than the baseline scenario, which provides $4.4 \%$ total energy savings. The $-50 \%$ case provides $1.1 \%$ total energy savings, $3.3 \%$ less than the baseline scenario. The $+50 \%$ case for combined rail LOS and commodity provides higher savings because more tons are shifted to the rail mode, which has lower energy intensity relative to truck. The total energy reduction in 2040 is expected to vary by about +/- 200 trillion Btu compared to the baseline scenario when percent shifted based on rail LOS alone is varied. The impact of percent shifted on the basis of commodity type alone is much smaller than that of rail LOS for the "High $(+50 \%)$ " case. This is because the percentages of tonnage shifted to rail for some commodity types were already $100 \%$ under the baseline scenario and remained unchanged here. Percentages of tonnage shifted for the commodity types that had baseline-scenario values higher than $66 \%$ were restricted to $100 \%$ here as well. The fourth and fifth sets (from the top) show the sensitivity analysis results for the minimum LOH (shown as "Min LOH") and minimum tonnage (shown as "Min Ton"). Their impacts are relatively small compared to the impacts of percent tonnage shifted based on rail LOS and commodity types. When the minimum tonnage threshold was

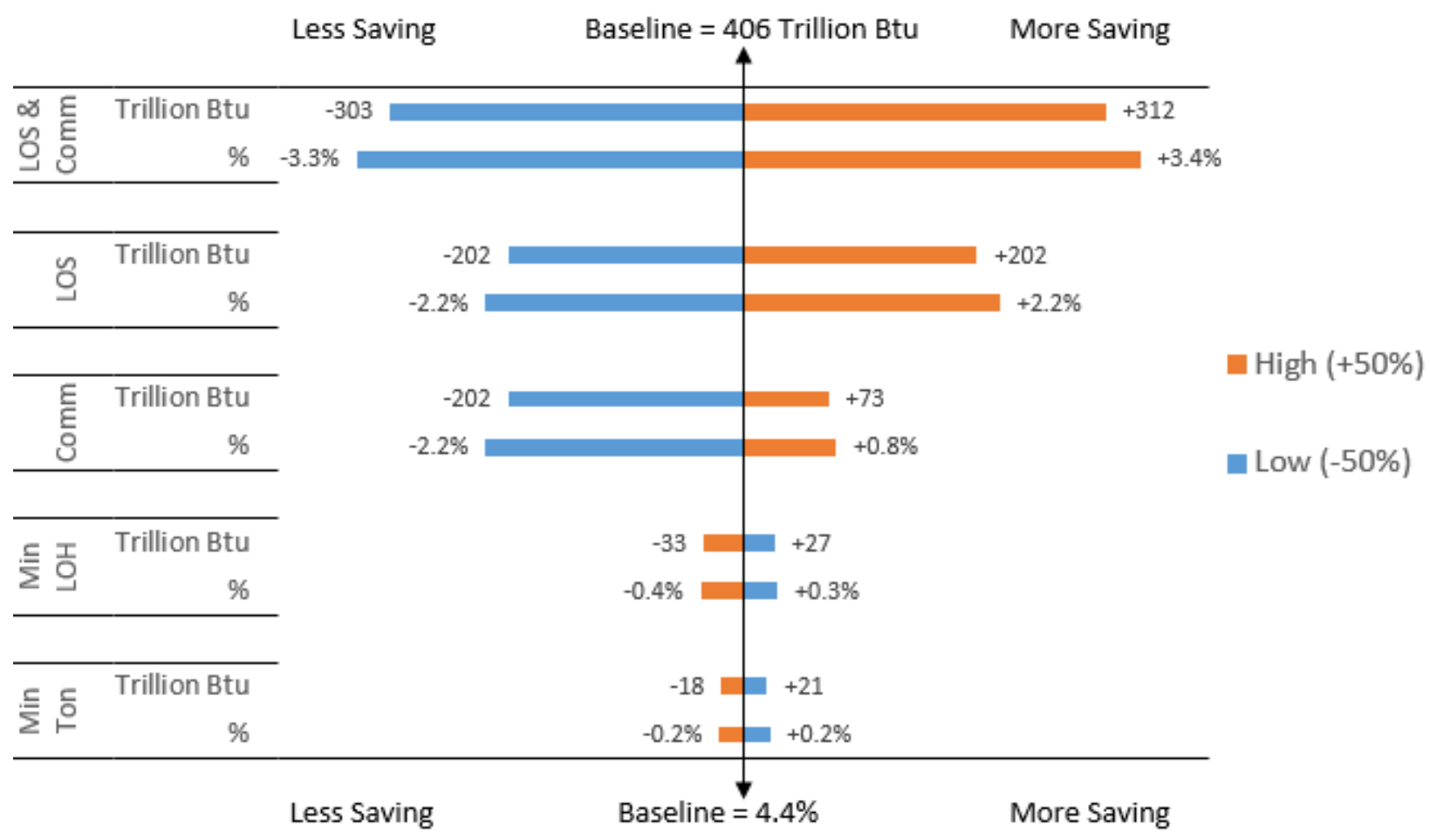

FIGURE 6 Sensitivity for Total Energy Savings in 2040 
lowered to 5,000, very few additional O-D pairs were added. On the other side, increasing the minimum tonnage threshold resulted in fewer O-D pairs.

Figure 7 shows how cumulative energy savings from 2016 to 2040 would change as a result of changes in inputs. Cumulative energy savings is sensitive to percent tons shifted depending on rail LOS and commodity type. When both of these inputs are changed, the cumulative energy savings by 2040 is expected to vary by about $+/-5000$ trillion Btu compared to the baseline scenario. The $+50 \%$ case provides $5 \%$ cumulative energy savings, $2.2 \%$ more than the baseline scenario, which provides $2.8 \%$ cumulative energy savings. The $-50 \%$ case provides $0.6 \%$ cumulative energy savings, $2.2 \%$ less than the baseline scenario. When varied individually, the cumulative energy changes from the baseline are symmetrical at $+/-$ 3,370 trillion Btu for percent tonnage shifted based on rail LOS. However, the cumulative energy savings changes are not symmetrical for percent tonnage shifted based on commodity. The cumulative energy savings are increased by 1,192 Btu from the baseline for the $+50 \%$ case and reduced by 3,372 Btu for the $-50 \%$ case. This is because many commodities had a value of $100 \%$ under the baseline scenario and could not be increased by $50 \%$, while the percent tonnage shifted could be reduced by $50 \%$ for all selected commodities. The cumulative energy savings changes for changing truck $\mathrm{LOH}$ and minimum tonnage for selecting an O-D pair are much smaller. The change from the baseline savings as a result of changing the truck $\mathrm{LOH}$ is -613 trillion Btu for the $+50 \%$ case and +504 trillion Btu for the $-50 \%$ case. The cumulative energy savings changes as a result of changing the minimum tonnage are even smaller, at -357 trillion Btu for the $+50 \%$ case and +424 trillion Btu for the $-50 \%$ case.

Figure 8 shows the GHG emissions results of the sensitivity analysis. GHG emissions ( $\mathrm{CO}_{2}$ equivalent) changes, relative to the baseline, could be $+/-26$ million MT in 2040 when both percent tonnage shifted based on rail LOS and commodity type are varied by $+/-50 \%$. The $+50 \%$ case provides $7.8 \%$ total GHG reduction, 3.4\% more than the baseline scenario, which provides $4.4 \%$ total GHG reduction. The $-50 \%$ case provides $1.1 \%$ total GHG reduction, $3.3 \%$ less than the baseline scenario. When only the percent shifted due to change in rail LOS is varied, the effect is +/- 17 million MT relative to the baseline scenario. When percentages shifted based on the commodity type are varied, the effect is -17 million MT for $-50 \%$ and +6 million MT for $+50 \%$, relative to the baseline scenario. Varying truck LOH results in a -3 million MT change from the baseline value for the $+50 \%$ case and a +2 million MT change from the baseline value for the $-50 \%$ case. Varying minimum truck tonnage results in a -2 million MT change for the $+50 \%$ case and a +2 million MT change for the $50 \%$ case.

Figure 9 shows changes in cumulative GHG emissions during the period 2016-2040, relative to the baseline in million $\mathrm{MT} \mathrm{CO}_{2}$ equivalent. Cumulative $\mathrm{GHG}$ emission change could be $+/-430$ million MT CO 2 equivalent (+/-2.2\%) by 2040 when both percentage shifted based on rail $\mathrm{LOH}$ and by commodity type are varied. The effect of $+/-50 \%$ change in the percent tonnage shifted based on rail LOS alone is $+/-287$ million MT relative to the baseline. The effect of changing the percent shifted based on commodity type is -287 million MT for the $-50 \%$ case and +101 million MT for the $+50 \%$ case. The effect of a $+/-50 \%$ change in truck $\mathrm{LOH}$ is +43 million MT for the $-50 \%$ case and -52 million MT for the $+50 \%$ case. The effect of changing minimum tonnage for selecting an O-D pair is +36 million MT for the $-50 \%$ case and -30 million MT for the $+50 \%$ case. 


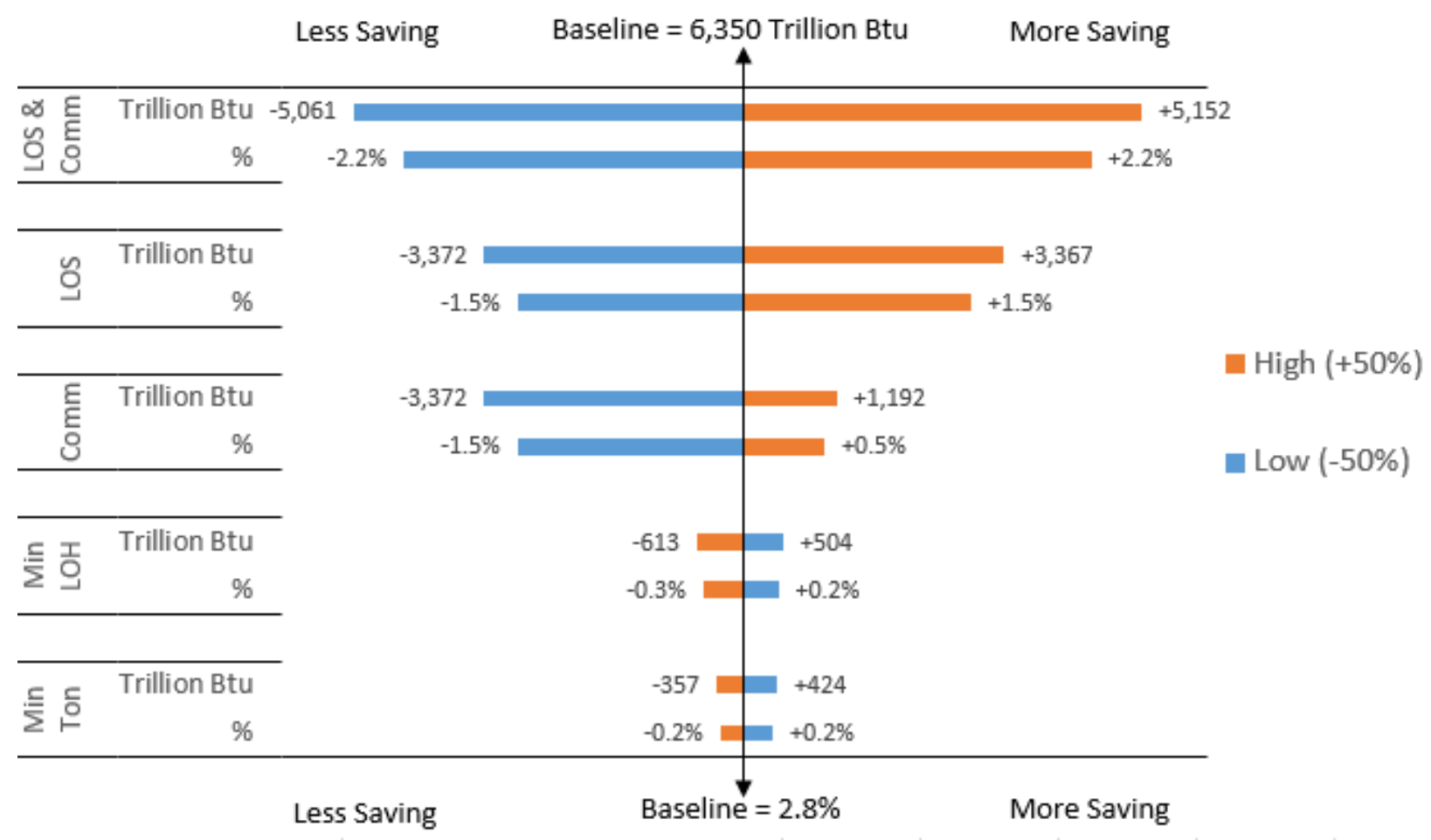

FIGURE 7 Sensitivity for Cumulative Energy Savings (2016-2040)

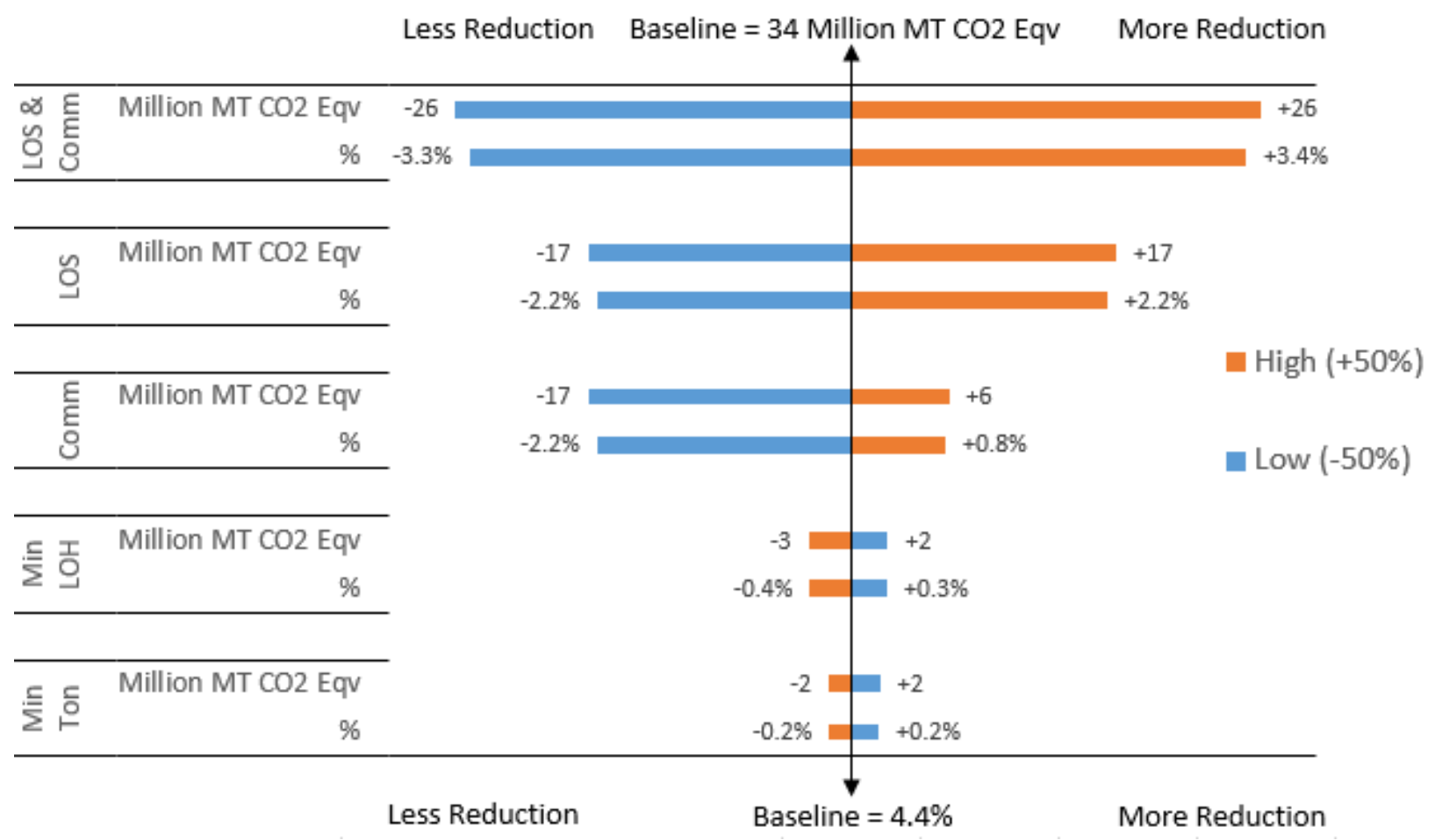

FIGURE 8 Sensitivity for GHG Reduction in 2040 


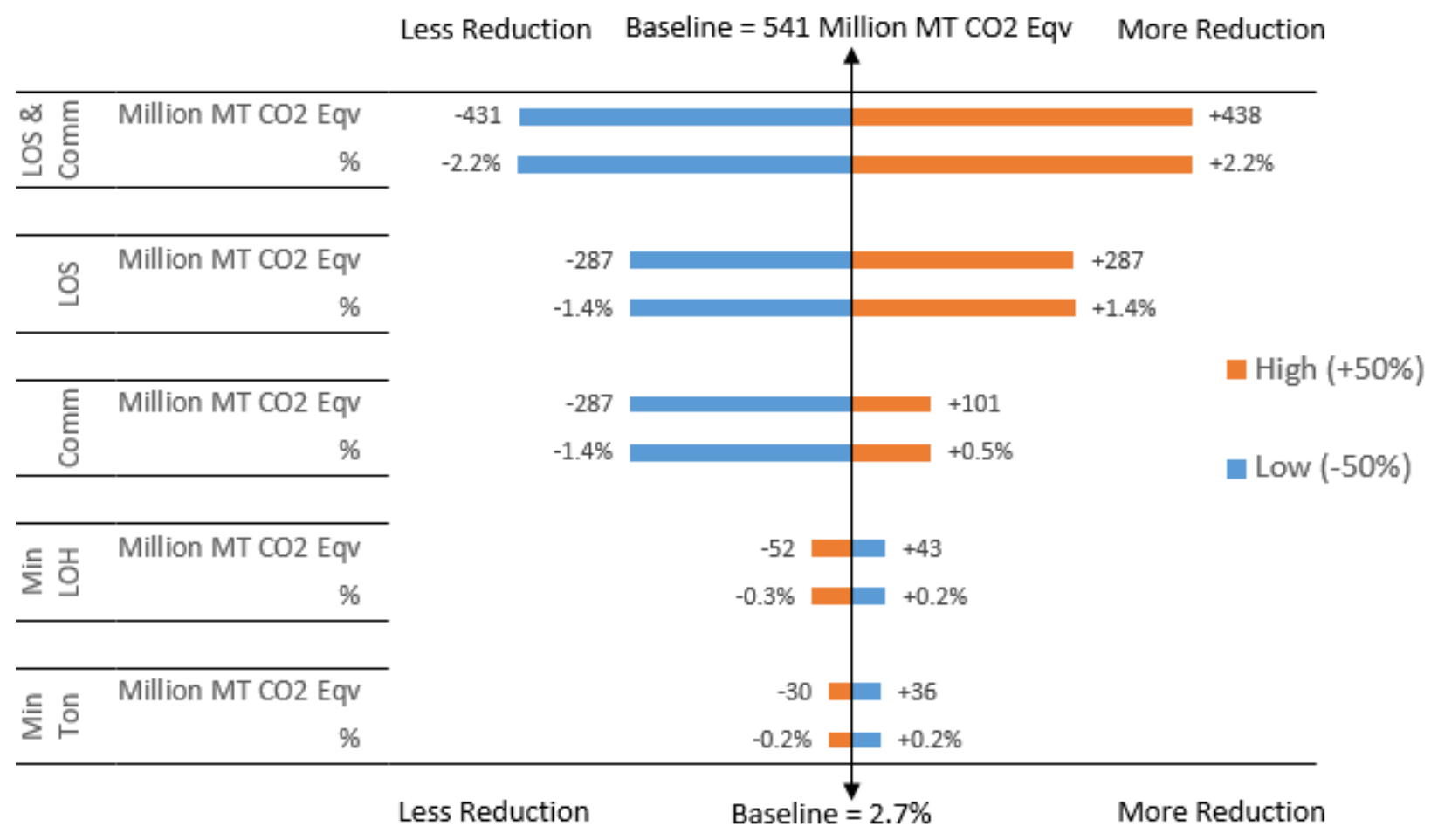

FIGURE 9 Sensitivity for Cumulative GHG Reduction (2016-2040) 


\section{DISCUSSION}

The objective of the analyses presented here was to investigate the extent to which a reasonable shift of freight from truck to rail would result in energy and GHG emissions changes. Because the rail mode is more efficient than truck, the potential shift could save energy and reduce GHG emissions. FHWA's FAF projections, EIA's energy commodity projections in AEO, and Argonne's NEAT model were used for this purpose. The FAF projections show a substantial increase in truck tonnage, which in turn reflects survey data. The survey data and FAF projections indicate that most shippers prefer the truck mode. There could be several reasons for this preference. Among them are the shift by manufacturers to just-in-time delivery of parts and components, the development of distribution systems that reduce retailers' inventory cost and require stocking their retail outlets only as needed, and the projected increase in on-line shopping in the future.

The baseline-scenario development involved a conservative approach to estimating shift of freight tonnage from truck to rail. Several low-volume, time-sensitive, and delicate commodities were omitted. Mode shift for the remaining commodities depended on four parameters: (1) Commodity-level mode shift percentage: Each selected commodity was evaluated for its extent of shift to rail and was assigned a mode shift percentage. (2) Rail LOS-based mode shift percentage: A rail LOS category was assigned to each O-D pair and a potential mode shift percentage was assigned to each LOS category. (3) Minimum truck LOH: Only the O-D pairs involving a longer truck LOH ( $\geq 300$ miles) were considered. (4) Minimum tonnage at O-D level: Only the large-volume ( $\geq 10,000$ tons) O-D pairs were selected. A conservative approach was followed while assigning potential shifts to rail based on commodity and rail LOS.

A sensitivity analysis was conducted. This analysis involved changing each of the four parameters individually by $+/-50 \%$. The $+50 \%$ analysis would represent optimistic values for mode shift percentage based on commodity and rail LOS. This would involve increasing mode shift potential and provide maximum energy savings and reduction in GHG emissions. However, increasing minimum truck $\mathrm{LOH}$ and minimum tonnage would result in fewer O-D pairs being selected. Because each parameter was varied individually, it was possible to see both the favorable and unfavorable impacts.

Our analysis shows that the mode shift percentage allocated on the basis of the rail LOS influences the freight sector energy and GHG emissions savings the most. While allocating mode shift percentage based on rail LOS, we took into account the fact that commodity flow surveys and FAF methodology show truck mode as a preferred mode for most commodities. Our intention was to present a reasonable scenario for shifting freight from truck to rail. We believe that the evaluation based on the baseline scenario is reasonable under the current conditions. The sensitivity analysis showed more energy savings, with a 50\% increase in mode shift potential based on the rail LOS.

For allocation of percentage of tons that can be shifted from truck to rail, the commodity was the next most influential parameter. Out of nineteen selected commodities, we had assigned 
$100 \%$ mode shift potential to nine commodities. One commodity was assigned $80 \%$, while the remaining nine commodities were assigned varying lower percentages. Here too, the sensitivity analysis showed that energy use and GHG emissions could be reduced substantially by increasing mode shift potential for the nine commodities further. The baseline scenario is appropriate under the current conditions. 


\section{CONCLUSIONS}

Under the baseline scenario, we found that only a $4.3 \%$ net energy savings and a $4.4 \%$ reduction in GHG emissions could be achieved by 2040 . These small numbers are the results of restrictions imposed while developing the baseline scenario. First, we omitted many commodities owing to the low volume of their transport by truck traveling over 300 miles. Second, we assigned less than $100 \%$ mode shift potential to 10 out of 19 selected commodities. Third, we assigned $66 \%$ mode shift potential to excellent rail LOS, $33 \%$ to good rail LOS, and $10 \%$ to moderate rail LOS. Fourth, we selected truck freight going a distance longer than 300 miles. Finally, we selected O-D pairs with 10,000 tons or more going by truck. Note that the $4.3 \%$ energy savings and $4.4 \%$ GHG reduction represent the national totals. Some individual O-D pairs may exhibit much higher percentages of energy savings and GHG reduction.

Here, we highlight some key conclusions.

- Under the baseline scenario, cumulative energy savings (upstream included) during the period 2016-2040 due to mode shift from truck to rail is about 1,475 trillion Btu by 2025, but rises to 6,350 trillion Btu by 2040 .

- Under the baseline scenario, the use of bio-fuels by the truck mode affects upstream energy use significantly. About a $6.3 \%$ reduction in total upstream energy use is attributed to truck and a $1.5 \%$ increase in total upstream energy use is attributed to rail, leading to about a $4.9 \%$ net reduction in total upstream energy use.

- The baseline scenario shows a reduction in total GHG emissions that is similar in magnitude to the reduction in total energy and upstream energy usage, about $4.4 \%$ by 2040 .

- Sensitivity analysis shows that the total energy savings and GHG reduction are more sensitive to percent tonnage shifted depending on rail LOS and commodity type. When varying percent tons shifted based on rail LOS and commodity type together by $+/-50 \%$ (of the baseline-scenario values), total energy savings and GHG reduction would range from $1.1 \%$ to $7.8 \%$ in 2040 .

- Sensitivity analysis shows that the total annual energy savings in 2040 would vary from $2.2 \%$ to $6.6 \%$ when percentage shifted based on rail LOS alone is varied by $+/-50 \%$ of the baseline scenario value.

- Sensitivity analysis shows that the cumulative energy savings (upstream included) by 2040 would vary by about +/- 5000 trillion Btu (+/- 2.2 \%) from the baseline scenario value of 6,350 trillion Btu when percent tons shifted based on rail LOS and commodity type are varied.

- Sensitivity analysis shows that cumulative GHG emissions during the period 2016-2040 could be $+/-430$ million $\mathrm{MT} \mathrm{CO}_{2}$ equivalent $(+/-2.2 \%)$ relative to the baseline when both percent shifted based on rail $\mathrm{LOH}$ and commodity type are varied. 


\section{REFERENCES}

CFS, 2006. 2007 Commodity Flow Survey, Standard Classification of Transported Goods $(S C T G)$, U.S. Census Bureau and Bureau of Transportation Statistics Report CFS-1200.

Davis, S.C., Diegel, S.W, and Boundy, R.G., 2015. Transportation Energy Data Book Edition 34, Oak Ridge National Laboratory Report ORNL-6991.

EIA, 2015. Annual Energy Outlook 2015-with Projections to 2040, U.S. Department of Energy Report DOE/EIA-0383, available at https://www.eia.gov/outlooks/aeo/pdf/0383 (2015).pdf.

EIA, 2016. Annual Energy Outlook 2016-with Projections to 2040, U.S. Department of Energy Report DOE/EIA-0383, available at https://www.eia.gov/outlooks/aeo/pdf/0383(2016).pdf.

FHWA, 2015. Freight Analysis Framework, available at https:/www.rita.dot.gov/bts/sites/ rita.dot.gov.bts/files/FFF_complete.pdf.

FHWA, 2016. Freight Analysis Framework, available at https://ops.fhwa.dot.gov/freight/ freight_analysis/faf/.

Komor, P., 1995. "Reducing energy use in U.S. freight transport." Transport Policy, 2(2): 119-128.

Kreutzberger, E., et al., 2003. "Is intermodal freight transport more environmentally friendly than all-road freight transport? A review." NECTAR Conference, Umea, Sweden.

Nealer, R., Weber, C., Hendrickson, C., and Matthews, H.S., 2011. "Modal freight transport required for production of US goods and services," Transportation Research Part E 47:474-489.

NPWI (National Ports and Waterways Institute), 2004. The Public Benefits of the Short-Sea Intermodal System. New Orleans: University of New Orleans.

Patterson, Z., et al., 2008. "The potential for premium-intermodal services to reduce freight $\mathrm{CO}_{2}$ emissions in the Quebec City-Windsor Corridor." Transportation Research Part D 13:1-9.

Vyas, A., 2014. "Non-light Duty Energy and Greenhouse Gas (GHG) Emissions Accounting Tool (NEAT) for Long Term Energy and GHG Impacts Evaluation: Domestic Freight Component Documentation and User's Guide," Argonne National Laboratory Report ANL/ESD-14/14, available at http://www.anl.gov/energy-systems/project/neat-non-light-dutyenergy-and-ghg-emissions-accounting-tool.

Winebrake, J.J., et al., 2008. "Assessing energy, environmental, and economic tradeoffs in intermodal freight transportation." Journal of the Air \& Waste Management Association, 58(8):1004-1013. 
Winebrake, J.J., and Corbett, J.J., 2010. "Improving the energy efficiency and environmental performance of goods movement." In: Climate and Transportation Solutions: Findings from the 2009 Asilomar Conference on Transportation and Energy Policy, ed. D. Sperling and

J.S. Cannon, Institute of Transportation Studies, University of California, Davis, pp. 203-216. 



\section{Argonne}

\section{Energy Systems Division}

9700 South Cass Avenue, Bldg. 362

Argonne, IL 60439-4854

www.anl.gov 